\title{
Association between A1298C and C677T methylenetetrahydrofolate reductase gene polymorphisms and the risk of acute lymphoid and myeloid leukemia
}

Yousef Mortazavi ${ }^{1},{ }^{2}$, Zahra Ghasemi ${ }^{3}$, Sanaz Aghajani ${ }^{4}$, Mohammad Eftekhari Shirkohy ${ }^{3}$, Minoosh Moghimi ${ }^{5}$, Alireza Khademolmelleh ${ }^{5}$, Saeideh Mazloomzadeh ${ }^{6}$

${ }^{1}$ Cancer Gene Therapy Research Center, Zanjan University of Medical Sciences, Zanjan, Iran ${ }^{2}$ Metabolic Diseases Research Center, Zanjan University of Medical Sciences, Zanjan, Iran

${ }^{3}$ Department of Medical Biotechnology, Faculty of Medicine, Shahid Beheshti University of Medical Sciences, Tehran, Iran

${ }^{4}$ Department of Hematology, Faculty Allied Health, Kerman University of Medical Sciences, Kerman, Iran ${ }^{5}$ Department of Internal Medicine, School of Medicine, Zanjan University of Medical Sciences, Zanjan, Iran ${ }^{6}$ Social determinants of Health Research Center, Zanjan University of Medical Sciences, Zanjan, Iran

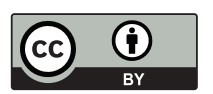

This work is licensed under a Creative Commons Attribution 4.0 International License

Received: 2020-05-30

Accepted: 2020-06-17

UDC: 618.1

J Clin Med Kaz 2020; 4(58):45-50

Corresponding author: Dr. Yousef Mortazavi,

Department of Pathology, Faculty of Medicine, Zanjan

University of Medical Sciences, Zanjan, Iran.

Post code: 45139 56111. Tel: +98 9123892427

E-mail: youmort@yahoo.com

\section{ABSTRACT}

Background: Methylenetetrahydrofolate reductase (MTHFR) is a key enzyme involved in folate metabolism, DNA methylation and synthesis. Two MTHFR polymorphisms, C677T and A1298C, have been associated with reduced enzyme activity. Rapidly replicating cell types, such as hematopoietic cells, may be especially sensitive to changes in the availability of intracellular folate. The aim of this case-control study was to evaluate whether the mentioned polymorphisms in MTHFR gene plays a role in altering susceptibility to acute myeloid leukemia and acute lymphoblastic leukemia.

Material and methods: 281 patients comprising 101 patients with acute lymphoblastic leukemia and 180 patients with acute myeloid leukemia as well as 490 normal individuals as control group were studied for the C677T and the A1298C MTHFR gene polymorphisms using PCR. The PCR products were digested with HinfI and MboII restriction enzymes respectively (RFLP). The results were electrophoresed on agaros gel and analyzed using SPSS software.

Results: The number of patients with acute lymphoblastic leukemia who had C677T polymorphism was less than the control group, but this difference was not significant. Also, combination of C677T/A1298C genotypes in both case and control groups, showed no increase of susceptibility to acute myeloid leukemia and/or acute lymphoblastic leukemia risk. There was no significant relationship between common MTHFR variants and the risk of acute myeloid leukemia and acute lymphoblastic leukemia in controls and the cases.

Conclusion: Our findings showed that the MTHFR C677T and A1298C gene variants do not have a major influence on the susceptibility to acute lymphoblastic leukemia and acute myeloid leukemia in Iranian individuals. However, the $\mathrm{C} 677 \mathrm{~T}$ polymorphism has a protection role in acute lymphoblastic leukemia group, but this difference was not statistically significant.

Key words: MTHFR, polymorphism, acute lymphoblastic leukemia, acute myeloid leukemia, PCR/RFLP

\footnotetext{
А1298С ЖӘНЕ С677Т МЕТИЛЕНТЕТРАГИДРОФОЛАТРЕДУКТАЗА ГЕНІНІН ПОЛИМОРФИЗМДЕРІ МЕН ЖЕДЕЛ ЛИМФОИДТЫ ЖӘНЕ МИЕЛОИДТЫ ЛЕЙКОЗ ҚАУПІ АРАСЫНДАҒЫ БАЙЛАНЫС

Ю. Мортазави ${ }^{1,2,3}$. Гасеми ${ }^{3}$ С. Агхаджани ${ }^{4}$, М.Э. Ширкоги ${ }^{3}$, М. Могими ${ }^{5}$, А. Хадемолмеллех ${ }^{5}$, С. Мазлумзадэ

'Обырдың генді терапиясы ғылыми-зерттеу орталығы, Зенджан медицина ғылымдары университеті, Зенджан, Иран

${ }^{2}$ Метаболиттік аурулар ғылыми-зерттеу орталығы, Зенджан медицина ғылымдары университеті, Зенджан, Иран

${ }^{3}$ Медициналық биотехнология кафедрасы, Медицина факультеті, Шахид Бехешти атындағы Медицина ғылымдары университеті, Тегеран, Иран

${ }_{4}^{4}$ Гематология кафедрасы, Емдеу ісі факультеті, Керман медициналық ғылым университеті, Керман, Иран

${ }^{5}$ Ішкі медицина кафедрасы, Медицина мектебі, Зенджан медицина ғылымдары университеті, Зенджан, Иран

6Денсаулықтың әлеуметтік детерминант ғылыми-зерттеу орталығы, Зенджан медицина ғылымдары университеті, Зенджан, Иран
}

\section{ТҰЖЫРЫМДАМА}

Мақсаты: Метилентетрагидрофолатредуктаза (МТГФР) - бұл фолий алмасуына, метилизацияға және ДНҚ синтезіне қатысатын негізгі фермент. Екі МТГФР полиморфизмі, С677Т және А1298C фрермент белсенділігінің төмендеуімен байланысты. Қарқынды репликация жасуша типтері, мысалы гемопоэтикалық жасушалар, жасуша ішілік фолаттың қол жетімділігіндегі өзгерістерге ерекше сезімтал болуы мүмкін. Бұл «жағдай-бақылау» зерттеудің мақсаты МТГФР геніндегі бұл полиморфизм жедел миелоидты лейкоз бен жедел лимфобластикалық лейкоз сезімталдықты өзгертуде рөл атқаратындығын бағалау болды. 
Материалдары және әдістері: Барлығы 281 пациент, оның ішінде өткір лимфобластикалық лейкозбен ауыратын 101 науқас және жедел миелоидты лейкозбен ауыратын 180 пациент, сондай-ақ 490 сау адам бақылау тобы ретінде МТГФР С677Т және А1298С гендік полиморфизмдеріне ПТР қолдана отырып тексерілді. ПТР өнімдері сәйкесінше Hinfl және Mboll ферменттерімен қорытылды (ПДРФ). Нәтижелер агарозды гель электрофорезіне ұшырады және SPSS бағдарламалық жасақтамасының көмегімен талданды.

Нәтижелері: C677Т полиморфизмі бар жедел лимфобластикалық лейкозбен ауыратын науқастардың саны бақылау тобына қарағанда аз болды, бірақ бұл айырмашылық айтарлықтай болған жоқ. Сонымен қатар, екі топтағы С677Т/А1298С генотиптерінің үйлесуі жедел миелоидты лейкозға және/немесе жедел лимфобластикалық лейкозға сезімталдықтың жоғарылағанын көрсетті. Жалпы МТГФР нұсқалары мен жедел топтағы миелоидты лейкоз бен жедел лимфобластикалық лейкоздың қауіптілігі арасында екі топ арасында айтарлықтай байланыс болмады.

Қорытынды: Біздің нәтижелеріміз МТГФР генінің С677Т және А1298С нұсқалары ирандық пациенттерде жедел лимфобластикалық лейкоз бен жедел миелоидты лейкозға сезімталдыққа айтарлықтай әсер етпейтінін көрсетті. Соған қарамастан, С677Т полиморфизмі жедел лимфобластикалық лейкозбен ауыратын науқастар тобында қорғаныш рөлін атқарады, бірақ бұл айырмашылық статистикалық маңызды болмады.

Негізгі сөздер: МТГФР, полиморфизм, жіті лимфобластты лейкоз, жіті миелоидты лейкоз, ПТР/ПДРФ

\section{СВЯЗЬ МЕЖДУ ПОЛИМОРФИЗМАМИ ГЕНА МЕТИЛЕНТЕТРАГИДРОФОЛАТРЕДУКТАЗЫ А1298С И С677Т И РИСКОМ ОСТРОГО ЛИМФОИДНОГО И МИЕЛОИДНОГО ЛЕЙКОЗА}

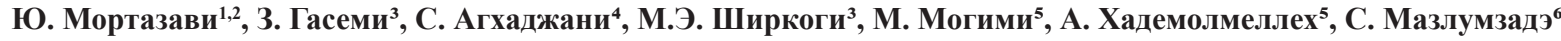

${ }^{1}$ Научно-исследовательский центр генной терапии рака, Зенджанский университет медицинских наук, Зенджан, Иран

${ }^{2}$ Научно-исследовательский центр метаболических заболеваний, Зенджанский университет медицинских наук, Зенджан, Иран

${ }^{3}$ Кафедра медицинской биотехнологии, Факультет медицины, Университет медицинских наук им. Шахида Бехешти, Тегеран, Иран

${ }^{4}$ Кафедра гематологии, Факультет лечебное дело, Керманский университет медицинских наук, Керман, Иран

${ }^{5}$ Кафедра внутренней медицины, Школа медицины, Зенджанский университет медицинских наук, Зенджан, Иран

${ }^{6}$ Научно-исследовательский центр социальных детерминант здоровья, Зенджанский университет медицинских наук, Зенджан, Иран

\section{PEЗЮME}

Цель: Метилентетрагидрофолатредуктаза (МТГФР) является ключевым ферментом, участвующим в метаболизме фолата, метилировании и синтезе ДНК. Два полиморфизма МТГФР, С677Т и А1298С, связаны со сниженной активностью фермента. Интенсивно реплицирующие типы клеток, такие как гемопоэтические клетки, могут быть особенно чувствительны к изменениям в доступности внутриклеточного фолата. Целью данного исследования «случай-контроль» было оценить, играет ли упомянутый полиморфизм в гене МТГФР роль в изменении восприимчивости к острому миелоидному лейкозу и острому лимфобластному лейкозу.

Материалы и методы: Всего 281 пациент, из них 101 пациент с острым лимфобластным лейкозом и 180 пациентов с острым миелоидным лейкозом, а также 490 здоровых людей в качестве контрольной группы были исследованы на полиморфизмы гена МТГФР С677Т и A1298C с помощью ПЦР. Продукты ПЦР расщепляли рестриктазами Hinfl и Mboll соответственно (ПДРФ). Результаты подвергали электрофорезу на агарозном геле и анализировали с использованием программного обеспечения SPSS.

Результаты: Число пациентов с острым лимфобластным лейкозом, у которых был полиморфизм С677Т, было меньше, чем в контрольной группе, но это различие не было значимым. Кроме того, комбинация генотипов С677Т/А1298C в обоих группах не показала увеличения риска восприимчивости к острому миелоидному лейкозу и/или острому лимфобластному лейкозу. Не было значимой связи между распространенными вариантами МТГФР и риском острого миелоидного лейкоза и острого лимфобластного лейкоза в обоих группах.

Заключение: Наши результаты показали, что варианты гена МТГФР С677Т и А1298С не оказывают существенного влияния на восприимчивость к острому лимфобластному лейкозу и острому миелоидному лейкозу у иранских пациентов. Тем не менее, полиморфизм С677Т играет защитную роль в группе пациентов с острым лимфобластным лейкозом, но это различие не было статистически значимым.

Ключевые слова: МТГФР, полиморфизм, острый лимфобластный лейкоз, острый миелоидный лейкоз, ПЦР/ПДРФ

\section{Introduction}

Leukemia is a group of hematologic malignancies that arise from a mutation within the hematopoietic stem cells. The etiology of leukemia is not clear completely that might be due to the multifactorial mechanisms of pathogenesis $[1,2]$. There is some evidence that leukemia is mostly as a result of an adverse interaction between environment and genetics associated with susceptibility being related to polymorphisms in different genes $[3,4]$. As clonal chromosomal abnormalities have reported in acute leukemia (AL), genetic variability in DNA repair or synthesis proteins may play an important role in associate to AL $[5,6]$. Polymorphism in folate pathway genes can influence the susceptibility to leukemia. Folate metabolism is essential for cellular functioning, because act as a donor of one-carbon groups for synthesis of thymidine, the building blocks of DNA, and also in methylation of homocyteine reactions [7,8]. Folate metabolism might disturb by nutritional deficiency, alter cellular transportation, and polymorphism in genes related to folate like methylenetetrahydrofolate reductase [1].

Methylenetetrahydrofolate reductase (MTHFR) has several polymorphisms, plays a key role in the risk of developing different diseases. A large number of studies have examined the association between polymorphisms of MTHFR gene and some cancers, diseases, and birth defect such as nonfamilial colorectal cancer, hepatocellular carcinoma, diabetic nephropathy, distal corectal adenoma, Down syndrome and spontaneous abortion [9-11]. There is some evidence that confirms the role of polymorphism in MTHFR-related genes in patients with ALL (acute lymphoblastic leukemia) and AML (acute myeloid leukemia) $[1,12,13]$. MTHFR is a key enzyme in the regulation of folic acid pathway and converts 5, 10-methylenetetrahydrofolate to 5-methyltetrahydrofolate. The gene which encoded this enzyme is located on the short arm of chromosome1 (1p36.6) [14]. Several polymorphisms of MTHFR enzyme have been identified from which the C677T and A1298C are the most important ones. C677T occurs in exon 4 and results in an alanine to valin change at codon 222 while the second common polymorphism A1298C, is transversion of A to $\mathrm{C}$ at position 1298 , results in glutamate to alanine in codon $7[15,16]$. These polymorphisms decrease the enzyme activity and change distribution of intracellular folate metabolites that cause accumulation of 5-10 MTHFR, the precursor for synthesis of purine and thymidylate $[16,17]$. These two polymorphisms lead to 30 to 60 percent of the MTHFR enzyme activity in both children and adults. Recently molecular epidemiological studies suggested that different and unknown alleles in MTHFR gene can reduce risk in AL progress [18-20]. This risk reduction is due to the accumulation and high levels 5-10 methylene tetrahydrofolate and leading to becoming more uracil to thymine by thymidilate synthase, in turn safeguard DNA failure of double strand and chromosomal abnormality [1,21]. To the best of our knowledge there is just one study that has been carried out on relationship between A1298C and C677T methylenetetrahydrofolate reductase gene polymorphisms and 
the risk of acute lymphoid and myeloid leukemias in Iran which has been done on low cases, and in other countries, studies has been conducted on an insignificant number of patients and the results obtained show contradictory so, in this study used more number of patients.

\section{Material and methods}

The study population consisted of 771 individuals (385 males and 386 females), their median age was 32 years (range, 1-89 years) comprising of ALL $(n=101)$, AML $(n=180)$, and healthy individuals without clinical disorder as normal controls $(n=490)$. Demographic data of study population are presented in Table 1.

AML and ALL were diagnosed by oncologists from Shariati, Dr. Gharib and Zanjan Hospitals by using a combination

Table 1 Socio-economic factors of the 388 cataract patients

\begin{tabular}{|l|l|l|}
\hline Study population & N & Sex (M:F) \\
\hline ALL & 101 & $50: 51$ \\
\hline AML & 180 & $90: 90$ \\
\hline Normal control & 490 & $234: 256$ \\
\hline Total & 771 & $385: 386$ \\
\hline
\end{tabular}

M: male; F: female; ALL: acute lymphoblastic leukemia; AML: acute myeloid leukemia.

of molecular tests, cytogenetics or immunophenotyping. Their medical records were retrospectively reviewed, and basic laboratory and clinical data were analyzed. This study was approved by Ethics committee of Zanjan University of Medical Sciences. Written informed consent was obtained from patients or parents of pediatric patients.

\section{Genotyping assay}

Genomic DNA was prepared from peripheral blood leukocytes using Bioneer AccuPrepK Genomic DNA Extraction kit (South Korea). Genotyping for MTHFR C677T and A1298C of all subjects was carried out by polymerase chain reaction restriction fragment length polymorphism (PCR-RFLP) assay. The primers for MTHFR C677T were forward 5'-TGA AGG AGA AGG TGT CTG CGG GA-3' and reverse 5'-GGA AGG
AGC TGA CCA GTG CAG TG-3'. The primers for MTHFR A1298C were forward 5'-CAA GGA GGA GCT GCT GAA GA3 ' and reverse 5'-CCA CTC CAG CAT CAC TCA CT-3. The following cycling conditions were performed: 5 min of initial denaturation at $95^{\circ} \mathrm{C}, 35$ cycles of $30 \mathrm{sec}$ of denaturation at $95^{\circ} \mathrm{C}$, $30 \mathrm{sec}$ of annealing at $62^{\circ} \mathrm{C}$, and $30 \mathrm{sec}$ of elongation at $72^{\circ} \mathrm{C}$ and $7 \mathrm{~min}$ of final extension at $72^{\circ} \mathrm{C}$. The 198 -bp PCR product of MTHFR C677T and 138-bp PCR of MTHFR A1298C were subject to enzyme digestion with HinfI and mboII $(22,23)$, respectively for $4 \mathrm{~h}$ and then visualized by DNA safe stain (FazA biotech, Iran) on 3\% agarose gel electrophoresis under UV light.

\section{Statistical analysis}

Only those participants having both genotyping and clinical data (control/case) were selected for final analysis. The descriptive statistics of patients and controls were presented as the mean standard deviations (SDs) or as percentages. The Pearson's chi-square test or Fisher's exact test was used to compare the distribution of the genotypes. Associations were expressed and evaluated as odds ratios (ORs) with 95\% confidence intervals (95\% CIs). Statistical tests were deemed significant when the P-value was less than 0.05. All statistical analysis were performed with SPSS 17 . There was no statistically significant difference in sex ratio between case and control groups.

\section{Results}

MTHFR polymorphism in ALL: The frequencies of MTHFR 677CC, 677CT, and 677TT were 56.4\%, 34.7\% and $8.9 \%$, in ALL patients $(\mathrm{n}=101)$, and $52.5 \%, 37.6 \%$, and $9.9 \%$ in controls respectively. The presence of variant genotypes, $677 \mathrm{CT}$, $677 \mathrm{TT}$ or both, showed no significant difference in the risk of ALL when using 677CC as a reference. For MTHFR 1298, the frequencies of 1298AA, 1298AC, and 1298CC genotypes were $38.6 \%, 46.5 \%$, and $14.9 \%$ in ALL patients, and $45.5 \%$, $39.6 \%$ and $14.9 \%$ in controls, respectively (Table 2). AC allele (heterozygous) in 47 ALL patients $(46.5 \%)$ was more frequent than control group. The risk of ALL in people with AC genotype was higher than those in $\mathrm{CC}$ homozygote. But there was no statistically significant difference with $\mathrm{P}$ value $>0.05$ ( $\mathrm{P}$ value $=0.29$ ). Normal homozygous genotype (1298AA) was higher in

Table 2 Distribution of MTHFR polymorphisms in ALL

\begin{tabular}{|l|l|l|l|l|l|}
\hline MTHFR genotype & ALL patients & Controls & OR (95\% CI) \\
\hline \multirow{3}{*}{ C677T } & CC & $57(\% 56.4)$ & $53(\% 52.5)$ & 1.00 \\
\cline { 2 - 6 } & CT & $35(\% 34.7)$ & $38(\% 37.6)$ & $10(\% 9.9)$ & $0.86(0.47-1.55)$ \\
\cline { 2 - 6 } & TT & $9(\% 8.9)$ & $0.84(0.32-2.22)$ & 0.72 \\
\hline \multirow{2}{*}{ A1298C } & AA & $39(\% 38.6)$ & $46(\% 45.5)$ & 1.00 \\
\cline { 2 - 6 } & AC & $47(\% 46.5)$ & $40(\% 39.6)$ & $1.39(0.76-2.53)$ & $1.18(0.51-2.71)$ \\
\cline { 2 - 6 } & CC & $15(\% 14.9)$ & 0.29 & 0.70 \\
\hline
\end{tabular}

Table 3 Distribution of MTHFR polymorphisms in AML

\begin{tabular}{|c|c|c|c|c|c|}
\hline \multicolumn{2}{|c|}{ MTHFR genotype } & AML patients & Controls & OR $(95 \% \mathrm{CI})$ & $\mathrm{P}$ \\
\hline \multirow[t]{3}{*}{ C677T } & CC & $90(\% 50)$ & $98(\% 54.1)$ & 1.00 & \\
\hline & CT & $75(\% 41.7)$ & $66(\% 36.5)$ & $1.24(0.8-1.91)$ & 0.34 \\
\hline & TT & $15(\% 8.3)$ & $17(\% 9.4)$ & $0.96(0.45-2.04)$ & 0.91 \\
\hline \multirow[t]{3}{*}{ A1298C } & AA & $70(\% 38.9)$ & $73(\% 40.3)$ & 1.00 & \\
\hline & $\mathrm{AC}$ & $91(\% 50.6)$ & $88(\% 48.6)$ & $1.07(0.7-1.67)$ & 0.73 \\
\hline & $\mathrm{CC}$ & $19(\% 10.6)$ & $20(\% 11)$ & $0.99(0.48-2.01)$ & 0.97 \\
\hline
\end{tabular}


the control group than in the case group.

MTHFR polymorphism in AML: In AML patients $(n=180)$, the frequencies of MTHFR 677CC, 677CT, and 677TT were $0.50 \%, 41.7 \%$ and $8.3 \%$, and in controls it was $54.1 \%, 36.5 \%$, and $9.4 \%$ respectively. The presence of variant genotypes, $677 \mathrm{CT}$, $677 \mathrm{TT}$ or both, showed no significant difference for the risk of AML when using 677CC as a reference. For MTHFR 1298, the frequencies of 12988AA, 129AC, and 1298CC genotypes were $38.9 \%, 50.6 \%$, and $10.6 \%$ in AML patients, and 40.3\%, 48.6\% and $11 \%$ in controls, respectively (Table 3 ).

\section{Discussion}

Leukemia is typically influenced by genetic predisposition and environmental factors. Polymorphism in the genes of folate pathways, which causes defects in enzymes involved in this pathway, may be effective on susceptibility to leukemia. One of the most important enzymes regulating folic acid pathway is methylenetetrahydrofolate reductase (MTHFR). Studies conducted on polymorphisms of the MTHFR enzyme, indicating the importance of this enzyme in diseases such as leukemia. So far, there has been many studies on the effect of different polymorphisms of MTHFR gene in relation to ALL and AML $[1,24,25]$, but the contradictory results have been obtained. This may be due to recruiting low number of patients in those studies. Therefore, in this study, we investigated the effect of C677T and A1298C polymorphisms of MTHFR gene in larger number of ALL and AML patients. In this study, 101 patients of children with ALL and the same number of control subjects were considered. The frequency of C677T allele (Heterozygote genotype) in control group was $37.6 \%$ (in 38 individuals) and in the case group was $34.7 \%$ (35 patients, $\mathrm{OR}=0.86$ with $95 \%$ $\mathrm{CI})$. These results indicate a decreased risk in patients' groups compared to the controls, but it was not statistically significant ( $p$ value $=0.61$ ). The frequency of $1298 \mathrm{CC}$ genotype in both, the ALL and the control group was $14.9 \%$, so our results show that the A1298C polymorphism has no effect on predisposition to ALL.

In an extensive study conducted by Schnakenberg et al in Germany on 443 patients with ALL and 379 controls, they found no significant relationship between MTHFR variants or combination of both variants (A1298C/C677T) and the risk of ALL [26]. The results of their study are in agreement with our results. Another study, which conducted by Balta et al. in Turkey on 142 children with ALL, they did not find a significant relationship between $\mathrm{C} 677 \mathrm{~T}$ polymorphism and the risk of ALL [27].

Some studies have indicated that C677T polymorphism is responsible for reducing the risk of ALL and some other studies, such as a study conducted by Alcasabas in the Philippines, have shown that $1298 \mathrm{CC}$ polymorphism is responsible for increasing the risk of ALL [28]. These findings are in contrast to results that have been reported from Western Europe and North America $[29,30]$.

In a study by Skibola et al on 71 patients with ALL and 114 healthy individuals, it was shown that individuals with 677TT and 1298CC and 1298AC genotypes have 3 to 14 times reduced risk [31].

This finding supports that the common polymorphisms of MTHFR against cancers such as colorectal cancer and especially ALL may have a protective role. This reduction risk may be due to MTHFR enzyme variants that reduce the activity of this enzyme, resulting in a cumulative and elevated level of 5 and 10 methylenetetrahydrofolate, which leads to greater conversion of uracil to timidine by timidilate synthase, and reducing the probability of getting uracil In DNA, that in turn, the DNA is retained from the fracture and a chromosomal change [32].

In this respect, contradictory results have been reported. Some studies supports the protective effects of MTHFR gene polymorphisms (A1298C and C677T) [33, 34], but some studies including our study reported only a weak risk reduction that was not statistically significant. Of course, these diverse results may be due to a lack of nutritional information, folate intake, or other measurements of folate reserves. Several studies have reported the effect of different MTHFR variants depends on the levels of folate test subjects. People with mutated homozygous genotype 677(TT), whose plasma folate concentration is normal have a lower risk of cancer than people with normal homozygous genotype $[34,35]$. This indicates a risk-dependent change in folate stores, that is, where folate is abundant in the cell, the folate molecules retain the mutant MTHFR protein in a functionally appropriate three-dimensional structure [36]. There are different explanations regarding the different results observed in different studies.

Racial differences, social, nutritional, genetic or environmental-gene interactions in different populations can lead to different results. We also examined the synergism of the two C677T and A1298C polymorphisms. In this study, the risk of people with (CT/AA) genotype was lower than those with both normal homozygotes (CC/AA) $(\mathrm{OR}=0.46)$.

We found no statistically significant relationship between these two polymorphisms and ALL risk. As a result, our findings indicate that ALL is not affected by A1298C and C677T polymorphisms.

MTHFR polymorphisms and AML: In this study we also investigated the effect of MTHFR gene polymorphisms (C677T and A1298C) and the risk of AML. For this purpose, $180 \mathrm{AML}$ patients and 181 controls were studied. C677T genotype was found in $75(41.7 \%)$ patients and in $66(36.5 \%)$ of the control group. No statistically significant difference was observed (OR $=1.24$ and confidence interval: $95 \%$ ).

In our study of A1298C genotype, no evidence of increased or decreased risk associated with AML was found, but a high percentage of polymorphisms were related to the 1298AC allele, the frequency of which was almost identical in both groups and in the total population studied was $49.6 \%$, more than in Asian countries. The two polymorphisms C677T and A1298C also showed no association with AML.

Willems et al. conducted a study on 78 AML patients under 15 years of age and found that the two major MTHFR polymorphisms (A1298C and C677T) were not associated with AML occurrence [35].

Skibola et al conducted a study on 237 AML patients and 337 controls and found no statistically significant difference between the case (AML patients) and controls, thus suggesting that C677T and A1298C polymorphisms of the MTHFR gene do not play a role in AML risk [31].

These results suggest that alteration in intracellular folate distribution by various forms of the MTHFR gene may affect lymphoid cells, but not myeloid cells. Most of the studies were carried out on low number of samples, but in our study the number of samples has been relatively larger, however, our results are consistent with the above studies and reject the effect of this polymorphism on the risk of AML.

Overall, our findings indicate that variants of the MTHFR gene (C677T and A1298C) did not have a significant impact on susceptibility to ALL or AML. However, other than the 
mentioned polymorphisms, the polymorphisms of other enzymes involved in the folate cycle may contribute to the susceptibility of people to leukemia.

Further research on other MTHFR gene polymorphisms to cause ALL or AML along with simultaneous measurement of folate levels seems to be necessary.
Acknowledgments: The results of this study were extracted from MSc student's thesis. This work financially was supported by Zanjan University of Medical sciences.

Disclosures: There is no conflict of interest for all authors.

\section{References}

1. Diab NA, Elderdery AY, Mills J, Khalil HB. The role of genetic polymorphisms of the MTHFR (C677T and A1298C) gene in the incidence of Acute Myeloid Leukaemia. Pakistani Journal of Medical and Health Sciences. 2019; 13(4):1330-4.

2. Qin Y-T, Zhang Y, Wu F, Su Y, Lu G-N, Wang R-S. Association between MTHFR polymorphisms and acute myeloid leukemia risk: a meta-analysis. PloS one. 2014; 9(2). https://doi.org/10.1371/journal.pone.0088823

3. Parsa N. Environmental factors inducing human cancers. Iranian journal of public health. 2012; 41(11):1.

4. Nichol JN, Kinal M, Miller WH. The etiology of acute leukemia. Neoplastic Diseases of the Blood: Springer. 2018; 161-77. https:// doi.org/10.1007/978-3-319-64263-5_12

5. Hansen B-A, Wendelbo $\varnothing$, Bruserud $\varnothing$, Hemsing AL, Mosevoll KA, Reikvam H. Sepsis in acute leukemia; epidemiology; pathophysiology, etiology and treatment. Mediterranean Journal of Hematology and Infectious Diseases. 2020; 12(1):e2020009-e. https://doi.org/10.4084/mjhid.2020.009

6. Abdelhalim DA, Elgamal BM, ElKafoury MR, Hassan NM, Hussein MM, Elhefnawi MM, et al. MicroRNA-150 down regulation in acute myeloid leukaemia patients and its prognostic implication. Open access Macedonian journal of medical sciences. 2018; 6(11):1993. https://doi.org/10.3889/oamjms.2018.420

7. Naushad S, Dorababu P, Digumarti R. Genetic variants of folate metabolic pathways in hematological toxicity of leukemia patients. Handbook of nutrition and diet in leukemia and blood disease therapy: Wageningen Academic Publishers. 2016; 291-302. https://doi. org/10.3920/978-90-8686-822-3 17

8. Liu P, Zhang M, Xie X, Jin J, Holman CDAJ. Polymorphisms of 5, 10-methylenetetrahydrofolate reductase and thymidylate synthase, dietary folate intake, and the risk of leukemia in adults. Tumor Biology. 2016; 37(3):3265-75. https://doi.org/10.1007/s13277-015-41686

9. Kuo C, Cheng C, Kuo H, Chen C, Huang C. Genetic Polymorphisms of One-carbon Enzymes Interactively Modify Metabolic Folate Stress and Risks of Hepatocellular Carcinoma Development. J Nutr Food Sci. 2016; 6(518):2. https://doi.org/10.4172/21559600.1000518

10. Wang D, Bai L, Zhai Q, Li Y, Cao M, Hai J, et al. Association of MTHFR C677T and A1298C polymorphisms with the development of type 2 diabetic nephropathy and their interaction with environmental factors. Int J Clin Exp Pathol. 2017; 10(3):3778-85.

11. Zhang S, Jiang J, Tang W, Liu L. Methylenetetrahydrofolate reductase C677T (Ala $>$ Val, rs $1801133 \mathrm{C}>\mathrm{T}$ ) polymorphism decreases the susceptibility of hepatocellular carcinoma: a meta-analysis involving 12,628 subjects. Bioscience reports. 2020; 40(2). https://doi. org/10.1042/BSR20194229

12. Garcia-Hernandez SC, Meneses-Sanchez P, Porchia LM, Torres-Rasgado E, Pérez-Fuentes R, Gonzalez-Mejia ME. Differential effects of the methylenetetrahydrofolate reductase polymorphisms (C677T and A1298C) on hematological malignancies among Latinos: a meta-analysis. Genetics and Molecular Biology. 2019; 42(3):549-59. https://doi.org/10.1590/1678-4685-gmb-2018-0161

13. Zhang B, Zhang W, Yan L, Wang D. The association between MTHFR gene C677T polymorphism and ALL risk based on a metaanalysis involving 17,469 subjects. Clinica chimica acta; international journal of clinical chemistry. 2017; 466:85-92. https://doi. org/10.1016/j.cca.2017.01.001

14. Şahin TG, Sayal B, Coşgun E, Besler T, Beksaç S. Methylenetetrahydrofolate reductase enzyme mutations and relationship of homocysteine Vitamin B12 and folate blood levels. Gynecology Obstetrics \& Reproductive Medicine. 2016; 19(1):1-6.

15. Garcia-Hernandez SC, Meneses-Sanchez P, Porchia LM, Torres-Rasgado E, Perez-Fuentes R, Gonzalez-Mejia ME. Differential effects of the methylenetetrahydrofolate reductase polymorphisms (C677T and A1298C) on hematological malignancies among Latinos: a meta-analysis. Genet Mol Biol. 2019; 42(3):549-59. https://doi.org/10.1590/1678-4685-gmb-2018-0161

16. Kaluzna EM, Strauss E, Swiatek-Koscielna B, Zajac-Spychala O, Gowin E, Nowak JS, et al. The methylenetetrahydrofolate reductase 677T-1298C haplotype is a risk factor for acute lymphoblastic leukemia in children. Medicine. 2017; 96(51):e9290. https://doi. org/10.1097/MD.0000000000009290

17. Akin DF, Oner DA, Sipahi K, Mumcuoglu M, Kurekci E, Ezer U, et al. Screening of polymorphisms in the folate pathway in Turkish pediatric Acute Lymphoblastic Leukemia patients. Egyptian Journal of Medical Human Genetics. 2017; 18(4):349-53. https://oi. org/10.1016/j.ejmhg.2017.03.003

18. Lien S-YA, Young L, Gau B-S, Shiao SPK. Meta-prediction of MTHFR gene polymorphism-mutations, air pollution, and risks of leukemia among world populations. Oncotarget. 2017; 8(3):4387. https://doi.org/10.18632/oncotarget.13876

19. Frikha R, Bouayed N, Ben Rhouma B, Keskes L, Rebai T. A duplex polymerase chain reaction-restriction fragment length polymorphism for rapid screening of methylenetetrahydrofolate reductase gene variants: Genotyping in acute leukemia. Journal of clinical laboratory analysis. 2018; 32(1):e22198. https://doi.org/10.1002/jcla.22198

20. Lv H, Hu SY, Du ZZ, Zhai Z, Cao L, Sun YN, et al. Gene polymorphisms in the folate metabolic pathway and risk of pediatric acute lymphoblastic leukemia: a case-control study in a Chinese population. Int J Clin Exp Pathol. 2018; 11(3):1724-31.

21. Hiraoka M, Kagawa Y. Genetic polymorphisms and folate status. Congenital anomalies. 2017; 57(5):142-9. https://doi.org/10.1111/ cga. 12232

22. Zhang L, Yin RX, Liu WY, Miao L, Wu DF, Aung LH, et al. Association of methylenetetrahydrofolate reductase C677T polymorphism and serum lipid levels in the Guangxi Bai Ku Yao and Han populations. Lipids in health and disease. 2010; 9:123. https://doi. org/10.1186/1476-511X-9-123 
23. Eloualid A, Abidi O, Charif M, El Houate B, Benrahma H, Louanjli N, et al. Association of the MTHFR A1298C variant with unexplained severe male infertility. PLoS One. 2012; 7(3):e34111. https://doi.org/10.1371/journal.pone.0034111

24. Long S, Goldblatt J. MTHFR genetic testing: Controversy and clinical implications. Australian family physician. 2016; 45(4):237-40.

25. Huang L, Deng D, Peng Z, Ye F, Xiao Q, Zhang B, et al. Polymorphisms in the methylenetetrahydrofolate reductase gene (MTHFR) are associated with susceptibility to adult acute myeloid leukemia in a Chinese population. Cancer epidemiology. 2015; 39(3):328-33. https://doi.org/10.1016/j.canep.2015.02.012

26. Schnakenberg E, Mehles A, Cario G, Rehe K, Seidemann K, Schlegelberger B, et al. Polymorphisms of methylenetetrahydrofolate reductase (MTHFR) and susceptibility to pediatric acute lymphoblastic leukemia in a German study population. BMC medical genetics. 2005; 6:23. https://doi.org/10.1186/1471-2350-6-23

27. Balta G, Yuksek N, Ozyurek E, Ertem U, Hicsonmez G, Altay C, et al. Characterization of MTHFR, GSTM1, GSTT1, GSTP1, and CYP1A1 genotypes in childhood acute leukemia. American journal of hematology. 2003; 73(3):154-60. https://doi.org/10.1002/ ajh.10339

28. Alcasabas P, Ravindranath Y, Goyette G, Haller A, Del Rosario L, Lesaca-Medina MY, et al. 5,10-methylenetetrahydrofolate reductase (MTHFR) polymorphisms and the risk of acute lymphoblastic leukemia (ALL) in Filipino children. Pediatric blood \& cancer. 2008; 51(2):178-82. https://doi.org/10.1002/pbc.21511

29. Krajinovic M, Lamothe Sp, Labuda D, Lemieux-Blanchard Em, Théorêt Y, Moghrabi A, et al. Role of MTHFR genetic polymorphisms in the susceptibility to childhood acute lymphoblastic leukemia. Blood. 2004; 103(1):252-7. https://doi.org/10.1182/blood-2003-06-1794

30. Ramirez-Pacheco A, Moreno-Guerrero S, Alamillo I, Medina-Sanson A, Lopez B, Moreno-Galvan M. Mexican Childhood Acute Lymphoblastic Leukemia: A Pilot Study of the MDR1 and MTHFR Gene Polymorphisms and Their Associations with Clinical Outcomes. Genetic testing and molecular biomarkers. 2016; 20(10):597-602. https://doi.org/10.1089/gtmb.2015.0287

31. Skibola CF, Smith MT, Kane E, Roman E, Rollinson S, Cartwright RA, et al. Polymorphisms in the methylenetetrahydrofolate reductase gene are associated with susceptibility to acute leukemia in adults. Proceedings of the National Academy of Sciences of the United States of America. 1999; 96(22):12810-5. https://doi.org/10.1073/pnas.96.22.12810

32. Pereira TV, Rudnicki M, Pereira AC, Pombo-de-Oliveira MS, Franco RF. 5, 10-Methylenetetrahydrofolate reductase polymorphisms and acute lymphoblastic leukemia risk: a meta-analysis. Cancer Epidemiology and Prevention Biomarkers. 2006; 15(10):1956-63. https://doi.org/10.1158/1055-9965.EPI-06-0334

33. Schnakenberg E, Mehles A, Cario G, Rehe K, Seidemann K, Schlegelberger B, et al. Polymorphisms of methylenetetrahydrofolate reductase (MTHFR) and susceptibility to pediatric acute lymphoblastic leukemia in a German study population. BMC medical genetics. 2005; 6(1):23. https://doi.org/10.1186/1471-2350-6-23

34. Pufulete M, Al-Ghnaniem R, Leather AJ, Appleby P, Gout S, Terry C, et al. Folate status, genomic DNA hypomethylation, and risk of colorectal adenoma and cancer: a case control study. Gastroenterology. 2003; 124(5):1240-8. https://doi.org/10.1016/S00165085(03)00279-8

35. Wiemels JL, Smith RN, Taylor GM, Eden OB, Alexander FE, Greaves MF, et al. Methylenetetrahydrofolate reductase (MTHFR) polymorphisms and risk of molecularly defined subtypes of childhood acute leukemia. Proceedings of the National Academy of Sciences. 2001; 98(7):4004-9. https://doi.org/10.1073/pnas.061408298

36. Pieroth R, Paver S, Day S, Lammersfeld C. Folate and its impact on cancer risk. Current nutrition reports. 2018; 7(3):70-84. https:// doi.org/10.1007/s13668-018-0237-y

How to cite this article: YousefMortazavi,Zahra Ghasemi, SanazAghajani, MohammadEftekhariShirkohy, MinooshMoghimi, Alireza Khademolmelleh, Saeideh Mazloomzadeh. Association between A1298C and C677T methylenetetrahydrofolate reductase gene polymorphisms and the risk of acute lymphoid and myeloid leukemia. J Clin Med Kaz. 2020; 4(58):45-50 